\title{
OPERA NINEI CASSIAN - REPERE DINTR-O „ARHEOLOGIE POETICĂ” LA PERSOANA I
}

\author{
NINA CASSIAN'S WRITINGS - MILESTONES \\ FROM A FIRST-PERSON "POETIC ARCHEOLOGY”
}

\author{
Alice NASTASE BUCIUTA ${ }^{1}$ \\ https://doi.org/10.52744/9786062613242.17
}

\begin{abstract}
Rezumat: Autoarea a peste 50 de volume de poezie şi proză - volume originale sau antologii în limba română şi în limba engleză, poezii pentru copii sau traduceri - Nina Cassian (1924-2014) este una dintre cele mai prolifice scrïtoare ale literaturii române, poetă de prim rang ale cărei merite, în urma relocării sale în America şi a creației sale în limba engleză, au fost recunoscute în întreaga lume. A debutat fulminant în $1947 \mathrm{cu}$ volumul La scara 1/1 care, deşi nu a primit recunoaşterea oficială a criticii aservite politic $\hat{\imath}$ an anii comunişti ai României, a marcat un moment semnificativ în istoria literaturii române şi a primit reverențele particulare ale lumii poetice. Următoarele sale 19 volume originale de poezie, scrise în limba română reflectă într-un stil original şi extrem de fidel volutele sale interioare, printr-un discurs poetic inegalabil ca diversitate şi creativitate. Din anul 1985 Nina Cassian este nevoită să se autoexileze în Statele Unite ale Americii, pentru a se salva de la prigoana securității româneşti şi, după câțiva ani de tăcere şi profundă suferință, renaşte în limba engleză regăsind poezia în limba țării de refugiu şi primind, astfel, şansa unor onoruri şi recunoaşteri internaționale. Moare la New York în anul în care ar fi trebuit să împlinească 90 de ani.
\end{abstract}

Cuvinte cheie: Nina Cassian; Poezie; Dragoste; Feminism; Exil; Comunism; Compoziție; Biografie; Bibliografie

\begin{abstract}
The author of over 50 volumes of poetry and prose - original volumes or anthologies in Romanian and English, poems for children, or translations - Nina Cassian (1924-2014) is one of the most prolific writers of Romanian literature, a leading poet whose work, following her relocation to the U.S. and her writing in English, has been recognized throughout the world. She made her debut in 1947 with the volume La scara $1 / 1$ which, although it did not receive official recognition within Romania itself during the communist regime, marked a significant moment in the history of Romanian literature and received particular reverence from the poetic world. Her next 19 original volumes of poetry, written in Romanian reflect in an original and extremely authentic manner her inner feelings, through an unparalleled poetic discourse of diversity and creativity. In 1985 Nina Cassian was forced into exile in the United States, to avoid persecution of Romanian security and, after a few years of silence and deep suffering, was reborn, as it were, in English, finding poetry in the
\end{abstract}

${ }^{1}$ Cercetător independent, Dr., independent scholar, alice@revistatango.ro 
language of her country of refuge and finally receiving recognition. She died in New York just short of her ninetienth birthday.

Keywords: Nina Cassian; Poetry; Love; Feminism; Exile; Communism; Composition; Biography; Bibliography

Cele peste 20 de volume originale de poezie în limba română ale Ninei Cassian, cărora li se adaugă un şir de antologii, câteva volume de proză, numeroase cărți de poezie pentru copii şi o întreagă serie de poeme adunate în volume de traduceri sau scrise direct în limba engleză, oferă material fertil şi de mare valoare pentru o istorie particulară a poeziei înțelese şi transpuse în toate stilurile sale posibile şi potenţiale, dar şi pentru compunerea unui portret emblematic, cuprinzător, al unui destin de artistă ce s-a autodefinit şi redefinit în repetate rânduri. Cu fiecare nouă apariție editorială, Nina Cassian a oferit lumii o altă fațetă a talentului său prodigios şi a minuțioasei sale introspecții poetice materializate în suite de poeme scrise în modalități nerepetitive, mereu uimitoare, dovezi ale unei personalități artistice de o complexitate inegalabilă, niciodată contrafăcută. Şi, din păcate, niciodată recunoscută şi recompensată la justa valoare de lumea literară românească.

Dincolo de poezie ca instrument al expresiei sale artistice, Nina Cassian a fost o muziciană de prim rang, pianistă şi compozitoare - de asemenea nerecunoscută în mediul cultural românesc, dar ale cărei compoziții au avut parte de câteva interpretări de mare virtuozitate în prestigioase teatre muzicale internaționale - şi o graficiană strălucită, care şi-a ilustrat singură câteva dintre volumele sale sau a îmbinat desenul cu poemul, într-o serie de creații nonconformiste ce ar merita, la rându-le, adunate şi admirate.

Nina Cassian s-a născut la Galați pe 27 noiembrie 1924 cu numele Renée-Annie Cassian-Mătăsaru, fiică unică a lui Iosif şi a Janei. Tatăl său era lucrător comercial, dar avea o aplecare nativă şi pasionată asupra lingvisticii şi poeziei, înclinație ce l-a făcut ulterior să devină traducător de poezie şi proză, în special din limba germană, şi să fie primit în Uniunea Scriitorilor. Mama sa a fost casnică întreaga viață, dar la rându-i avea o aplecare vie şi înfocată spre artă. Părinții Ninei Cassian cântau împreună muzică clasică, mama interpreta "cu o voce mică, dar exactă, de soprană" lieduri de Schubert, în timp ce tatăl o acompania la pian. „Casa noastră răsuna de poezie şi muzică şi, bineînțeles, le sunt recunoscătoare părinților mei pentru atmosfera artistică în care m-am format" îşi aminteşte Nina Cassian într-unul dintre interviurile sale şi evocă această atmosferă nobilă în numeroase pagini ale spectaculosului său jurnal intitulat Memoria ca zestre. Tatălui său îi atribuie şi dezvoltarea abilității sale speciale de a jongla cu cuvintele limbii române. „Cuvintele mi-au 
prins tare bine în viață şi le datorez, în mare măsură, mai ales la început, tatălui meu, care era fascinat de lingvistică, deşi n-avea şcoală, doar câteva clase de liceu. Iată un amănunt amuzant: tata era atât de pasionat de cuvinte, încât, la un moment dat, spunea şi prostii. Căuta tot felul de explicații, de înțelesuri noi şi, odată, îmi amintesc că găsise el de cuviință că expresia «a nimerit orbul Brăila» se referă la Braille! Şi i-a scris asta lui Alexandru Graur, care i-a răspuns: «Nici vorbă!». Dar important este că tata m-a învățat să am curaj să-mi imaginez şi să lucrez cu cuvintele”...

Ca oraş al copilăriei, Nina Cassian fixează în memoria sa afectivă nu Galațiul, de care nici nu-şi aminteşte, ci oraşul de munte în care părinții săi se mută când fetița avea doi ani: „Braşovul este oraşul fermecat al copilăriei mele fericite", decretează Nina Cassian, deşi, după mutarea familiei în Capitală, în 1935, când Nina avea 11 ani, învață să iubească şi Bucureştiul, oraşul în care, de altfel va începe curând să primească confirmări esențiale ale talentului său multifațetat de artistă.

Tudor Arghezi îi citeşte poemele scrise până la vârsta de 16 ani şi notează pe manuscris, printre altele: „Talent incontestabil. Vocație sigură”. Aceleaşi atestări vocaționale le va primi şi din partea marilor muzicieni care o îndrumă în adolescență ca pianistă şi compozitoare (Theodor Fuchs, Paul Jelescu, Mihail Jora, Constantin Silvestri), a pictorilor renumiți ce o ajută să se perfecționeze în artele plastice (George Lövendal şi Max Hermann Maxy) sau a maeştrilor ce o învață arta actorului (Beate Fredanov şi Alexandru Finți).

Nina Cassian excela în toate şi avea o uşurință extraordinară a învățării care, de altfel, o va ajuta inclusiv să dea ultimele două clase de liceu într-un singur an. Faptul că a ales ca studii superioare filologia chiar dacă nu şi-a terminat studiile universitare - şi nu artele plastice, teatrale sau muzicale, poate fi o dovadă că Nina Cassian a înțeles, totuşi, de la început de drum, că scrisul va fi tărâmul împlinirii sale. Pe de altă parte, având în permanență drept contrapunct celelalte arte care au încercat să o revendice şi de care a fost atrasă, Nina Cassian a păstrat în permanență un ochi al analizei lucide, deschis asupra propriului destin literar pe care l-a construit combinând în mod straniu disperarea cu detaşarea, aşezând unele peste altele straturi culturale, emoţionale şi naturale, într-o originală construcție de artă şi existență autoanalizată şi nuanțată asumat, cel mai adesea la persoana întâi singular.

„Bibliografia noastră e întrețesută cu biografia uneori până la promiscuitate" (Cassian 1997, 5) va admite Nina Cassian în prefaţa volumui DesFacerea lumii, apărut în anul 1997, la 73 de ani, vârstă la care, deşi îndrăgostită cu iubire proaspătă şi recent recăsătorită cu un muzician american, poeta şi-a întors privirea analitică înspre trecut cu o luciditate mai profundă ca niciodată. Către propria viață şi straturile bibliografice şi 
biografice ale unui trecut artistic a cărui posteritate le va deveni, cititorilor, paradoxal, iar şi iar, doar clipă nobilă a revelației prezente.

La scara 1/1, volumul de debut al Ninei Cassian, a apărut în anul 1947 şi a prezentat lumii o poetă curajoasă, spumoasă, ridicată original deasupra lecturilor sale aprofundate din poezia franceză modernă şi doar delicat influențată de opera celor doi poeți români venerați, Tudor Arghezi şi Ion Barbu. Volumul adună în cele 30 de poeme memorabile ale sale un univers suprarealist fascinant, în care elementele universului se îmbină în ipostaze complet neaşteptate cu cele ale naturii grandioase, într-o poezie cerebrală şi totuşi de-o delicatețe imposibil de mascat, chiar dacă ritmurile sunt tăioase şi lipsite de melodicitate, iar majoritatea rimelor sunt asonante. Nina Cassian îşi prezintă, de fapt, la dimensiunea lui reală, la scara 1/1, propriul suflet tânăr, curajos de viață, îndurerat de moarte, cutreierat de grație, bântuit de umor sau lehamite, ars de dragoste, ispitit de ironie, temător de trecerea timpului.

Am înotat o bună bucată de vreme

Şi-am prins gust de înec. Nu mă tem,

Tot aşa cum mă prinde gustul de poem

După ce-am citit o sută de poeme.

(„Golful nesigur”, La scara 1/1)

Ce zgomot făceau pasărea şi ploaia!

În geam, în mâini, cerul mare spărgea!

Am supt covorul, rufele şi ce mai rămânea -

Noi amândoi umpleam toată odaia.

Noi amândoi. Era vânt. Nu era.

(Cine ține minte? Cine vrea să mintă?)

Strâns ne-am ținut ca un om în oglindă,

Unul în abruptul frig al altuia.

(„Muntele cu dragoste”, La scara 1/1)

Eu am ştiut că timpul o să treacă.

Eu am ştiut.

Februarie e cel mai scurt

Şi-mi rămâne plânsul afară din teacă.

(„Tumefiere”, La scara 1/1)

Aud o harpă.

Urechea încă nu e oarbă.

Dacă mă cheamă, se poate

Să fie vorba de moarte.

Ce mai palpită, viperă,

Inima liberă, liberă! 
Un rămas-bun scurt,

Ochiul încă nu e surd.

Pe mormânt voi îngriji

Să-mi stea-n limbă străină: $C i g \hat{\imath} t^{*}$...

* Aici zace (fr.)

\section{(„Epitaf”, La scara 1/1)}

Volumul de debut al Ninei Cassian - splendid şi esenţial în istoria literaturii române - este primit cu ostilitate de critica de partid, realizată din perspectivă populist-politică. „Stranie, mare poezie!”, consemnase pe manuscrisul volumului La scara 1/1 poetul Ion Barbu, însă critica oficială, prin glasul autorităților vremii, Traian Şelmaru (rămas în istoria literaturii ca autor al butadei oferite scriitorilor drept îndrumare: „Lozinca e un lucru sfânt!”) şi Ovid S. Crohmălniceanu, nu-i autentificaseră măreția şi-l catalogaseră drept un volum formal şi decadent, duşmănos, lipsit de respect față de popor.

Acesta este, probabil, cel dintâi moment esențial în care bibliografia Ninei Cassian se întrepătrunde esențial cu biografia. Poeta, artista, femeia - trăieşte o suferință atât de profundă în urma receptării criticilor demolatoare, încât cariera sa cunoaşte un recul, printr-o schimbare radicală de abordare. Comentariile legate de volumul său de debut, îndelung pregătit şi aruncat în lume cu ambiția vie şi dorința autentică de a redesena lumea întreagă în 30 de poeme (M-a-ntrebat omul, fratele meu, bunul,/ De ce „La scara unu pe unu”?/ „Mult aş vrea - i-am răspuns la'ntrebare - / Să prind lumea cât îi de mare”) „i-au schimonosit temporar cariera”, aşa cum a considerat Nina Cassian, niciodată vindecată de îndurerarea că ofranda ei poetică, de enormă valoare literară şi, categoric, sufletească, nu a fost receptată aşa cum sperase şi aşa cum ar fi meritat. Ca într-un discurs premonitoriu, în poemul final al volumului La scara 1/1, „Pe curând”, Nina Cassian privea lucid spre conformările viitoare:

Mă uit cum drumurile mele se gudură,

Ţinute de hățuri, cu botul albit.

Cetăți viitoare de departe-mi scutură

Steagurile mici de bun-venit.

(„Pe curând”, La scara 1/1)

Au urmat zece ani în care drumurile artistice ale Ninei Cassian s-au gudurat ori s-au împotmolit, în vreme ce poeta încerca să se integreze vremurilor trăite: „Adaptarea mea (chinuită, dar parcursă - hélas! - cu deplină bună-credință) m-a costat o gravă pierdere de sânge artistic, întrun amestec de adeziune, anxietate şi contrarietate, rele conducătoare de inspirație" (Cassian 1993, VI).

Sunt anii volumelor aproape complet nesemnificative din perspectivă artistică, Sufletul nostru (1949), An viu nouă sute şi şaptesprezece (1949), 
Ce-a văzut Oana -poezii pentru copii (1952), Horea nu mai este singur (1952), Tinerețe (1953), Florile patriei (1954) şi ai antologiei Versuri alese (1955). Sunt anii aşezați sub un angajament poetic asumat.

Adun o comoară de zile

Trăindu-le cald şi adânc

- Si-acuma, condeiule, zi-le

Şi fă-le să sune în cânt.

Să semăn în cântecul meu

Mărețul urcuş către creste,

Să-i dau o putere mereu

Mai demnă de zilele-aceste.

(„Angajament”- Horea nu mai este singur)

Ca într-o ironie a sorții, nici aceste compromisuri artistice nu-i aduc râvnitele reverențe din partea criticii.

„Cu toate eforturile mele, am fost învinuită în continuare, pe durata a încă şapte ani, că nu m-am debarasat cu totul de «rămăşițele decadente» (constând probabil în urmele de "profesionalism», încă vizibile), ba chiar cea mai «proletcultistă» plachetă a mea, Horea nu mai este singur, a fost taxată de Paul Georgescu drept «o virulentă manifestare de formalism». În 1955 m-a cuprins o inapetență pentru poezie - definitivă, mă temeam eu." (Cassian 1993, VII)

Însă nu a fost aşa. Nina Cassian revine în 1957 (după zece ani de rătăciri şi promise renunțări!) cu Vârstele anului, care oferă, înşelător, ofrandă zeilor dictaturii primul ciclu de poeme din carte, intitulat Cred Muzeul de antichități şi cel de final, Cancerul Lumï - Călătorii, între care volumul creşte frenetic în adoraţia anotimpurilor şi slava iubirii trăite pătimaş. "Se dăduse drumul la dragoste. Şi la peisaj. Ape freatice zăgăzuite atât amar de vreme au erupt și am scris atunci zeci şi zeci de poezii spre slava iubirii şi a anotimpurilor, filon care a continuat şi în volumul următor, Dialogul vântului cu marea, şi în Sărbătorile zilnice, şi în Spectacol în aer liber." (Cassian 1993, VII) scrie, peste ani, Nina Cassian.

Vara este cea dintâi între vârstele anului şi ale poeziei Ninei Cassian, vara cu mările ei învecinate, vara cu iubirile ei înfierbântate din care poeta nu vrea să se desprindă nici în vis, nici în stare de veghe.

Am visat azi-noapte sărutări,

Câmpuri de garoafe zdrențuite.

Soarele cu zveltele-i cuțite

Înjunghiase cele patru zări -

Sânge picura pe sărutări. 
Aerul, ca-n preajma unui rug, Răspândea fluida lui rugină;

Gura de săruturi mi-era plină, Aș fi vrut, dar nu puteam să fug Pâlpâia tot câmpul ca un rug.

O pădure, platoşele-i verzi

Adiau departe, în răcoare,

Zdrențe de garoafe la picioare

Mi-arătau cât mai aveam de mers

Pân' să-ajung la platoşele verzi.

Şi-am rămas în sărutări arzând.

Cruntul soare izgonise norii;

Scuturile verzi ale răcorii

$\mathrm{Nu}$ aveam să le ating nicicând -

Sărutam garoafele arzând...

(„Patima” - Vârstele anului)

Anotimpurile aşezate în cuvânt vin mai departe cu tristețile sau bucuriile lor îndrăgostite, cu aşteptări mistuite de dorință, de zădărnicie sau de lăcomie, în poeme romantice, scrise în anii cei mai frumoşi şi mai intenşi, în plan personal, ai tinereții poetei.

Lacomă sunt. Mă ceartă asceții

că parcurg pe nerăsuflate

tabla de materii a vieții

şi că râvnesc şi mi-e poftă de toate.

Mă ceartă că beau şi mănânc

bucurii, deznădejdi, laolaltă

cu smântâna din urciorul adânc

şi cu mămăliga cea caldă.

Mă ceartă că port un ac la cravată

şi o garoafă în păr,

că mi-e vorba prea iute necumpătată

şi nu mai ştiu ce,-ntr-adevăr!

Că nu-mi împart dragostea chiar

după plan şi pe rații;

că-am fragede mâini de olar

şi rezolv uneori ecuații.

Ei, da, ce să-i faci? Mi-e foame, mi-e sete.

Ca sunetul umblu prin lumea cea vie.

$\mathrm{Nu}$ cunosc mersul pe îndelete

nici sărutul pe datorie. 
Lacomă sunt. Şi sorb şi-nghit şi zbor

şi-s mândră că la reveru-mi subțire,

sclipind, mă decorează uneori

rozeta ta de aur, fericire!

(„Rezolv uneori ecuații”, Vârstele anului)

Ziceam că va fi sărbătoare...

$\mathrm{N}-\mathrm{a}$ fost.

Şi-aşa, am purtat fără rost

veştmintele scăpărătoare.

Te-am aşteptat până-n zori, noaptea toată.

Vinul lâncezi în urcior,

fu pâinea pe masă, uscată.

Şi când a fost zi-ntr-adevăr

- şi-aşa avea să rămână -

mi-am scos cu o mână bătrână

floarea din păr.

(„Tristeți de primăvară- III”, Vârstele anului)

Iar poemele emoționale continuă pe alte ritmuri, dar la fel de adânc legate de suflet şi de peisaje nuanțate în toate culorile dorului, fie că sunt înstelate de fericire, fie îndurerate, în Dialogul vântului cu marea (1957) - volumul iubirii trăite pe tărâmurile bulgare de care poeta e îndrăgostită.

O, cum mai țipau, o, cum mai boceau păsările-n noapte o, cum hohoteau!

Trează stam în noapte, cu ochii deschişi, şi-n întreg oraşul, pe acoperiş, păsările mării clămpăneau din ciocuri. Ce râs, ce desmăț!

Recile batjocuri mă căutau pe mine prin singurătăți. $\mathrm{O}$, cum hohoteau, stranii citadine, păsările-n noapte. Asta e durerea, îmi spuneam, veghind. Aşa-i când te doare.

Ce asurzitoare aripi de argint, 
glasuri, ciocuri, ghiare,

lungi cuțite-n noapte,

pliscuri lângă geam...

... şi erai departe,

şi nu ne iubeam.

(„Durerea”)

Sărbătorile zilnice, volumul apărut în 1961, aşază, alături de elogiile dragostei trăite ardent la timpul prezent, primele întoarceri în timp către vârstele trecute, primele dezgropări de straturi create din revelațiile adunate în ani.

Dacă mă-ntorc, copilărie, la tine,

e poate semnul că scapăt.

E poate vremea să leg capăt de capăt,

cu-o singură mişcare străvezie.

Cutreier locul cel vechi şi ascult

rumorile-amintirii... Ziua de azi

o caut într-o zi de demult,

şi-n albine, şi-n brazi.

La noile mele dimensiuni, priveliştile par strâmte.

Chiar nara abia mai simte

mireasma trecutei minuni.

Creşte ecou din ecou,

dens ca o apă.

Dau munții deoparte, să-ncapă

sufletul meu cel nou.

(„Din copilărie” - Dacă mă-ntorc, Sărbătorile zilnice)

Am luat hotărârea să nu mă despart niciodată

de copilărie, de adolescență, de tinerețe,

ci să-mi trăiesc simultan toate vârstele,

ca trunchiul de copac să fiu propriul meu calendar,

să-mi simt brațele puternice, răbdătoare, în iarnă,

şi gata să tresară în primăvară

sub exuberanța verde a frunzei.

(„Din copilărie” - Toate vârstele, Sărbătorile zilnice)

Este perioada în care poemele sale de dragoste primesc, în sfârşit, adeziunea criticii oficiale, prin glasul lui Perpessicius, iar poeta răsuflă, întrucâtva, uşurată, dar fără să-şi poată masca nemulțumirea că opera sa este catalogată şi analizată sub umbrela termenului pe care îl consideră pe bună-dreptate - discriminator: lirică feminină. 
„Am mai protestat şi altă dată (zadarnic!) împotriva ideii fixe a criticilor de a vorbi despre o lirică «feminină» ca despre un capitol aparte al literaturii, în timp ce poezia scrisă de bărbați nu e niciodată taxată drept lirică masculină, ci lirică pur şi simplu (...) Ultimul volum al Gabrielei Melinescu este o nouă dovadă a înscrierii unei femei în primele rânduri ale poeziei, fără niciun epitet discriminatoriu" (Cassian 1968, 36) scria Nina Cassian într-o recenzie a sa făcută celui mai recent volum al Gabrielei Melinescu, în revista Femeia a anului 1968. Iar câțiva ani mai târziu, în aceeaşi revistă, Nina Cassian revine cu un răspuns tranşant acordat la una dintre întrebările primite de la jurnalista Alice Mihalcea.

„- De ce credeți că se discută în termeni de literatură masculină şi literatură feminină? Prima fiind investită cu atribute ca idei, inteligență, cealaltă doar cu sentiment?

- Este un semn de discriminare. Pentru că atâta vreme cât în nicio istorie a literaturii niciun capitol nu este dedicat literaturii masculine, nu are sens ideea de literatură feminină. Decât dacă o consideră ca o faptă de mirare, o producție cu caracter limitat, un fel de ciudățenie. Iar în ce priveşte ideea despre bărbați ca depozitari ai inteligenței şi forței şi despre femei ca depozitare ale sentimentului şi gingăşiei, aş spune că este tot o secționare brutală. Îmi permit să cred cu încăpățânare că suntem toți oameni, depozitari ai tuturor acestor calități.

Un bărbat ar întreba care sunt argumentele concrete. Şi o femeie ar răspunde: căutați-le în condiția noastră socială trecută şi dibuiți-le în cea viitoare... (Cassian 1972, 27)

Acesta poate fi un argument sau, mai degrabă, un motiv al refugiului scriitoarei în poezia intelectuală, cerebrală, atent şi minuțios elaborată. O altfel de poezie pe care, de altfel, Nina Cassian o defineşte într-o artă poetică creată în stil neo-modernist:

De la acest creion porneşte un drum de grafit,

şi pe drum umblă o literă ca un câine, şi iată un cuvânt ca un oraş locuit

în care, poate, voi ajunge mâine.

$$
\text { („Poezia” - Disciplina harfei) }
$$

Iubirea însăşi este abordată diferit în poem, cu ceea ce critica interpretează drept un soi de răceală, însă Nina consideră a fi doar o „fierbinte cerebralitate”, după modelul asumat al lui Bertold Brecht. (Cassian 1993, IX)

Mereu îmi aflu perechea.

Iată zâmbetul meu

pe buzele altora.

Când mă privesc în oglindă,

îmi recunosc semenii. 
Sunt coruri în cântecul meu

şi fac parte din milioane de cupluri.

Am desenat o dată

o fantastică floare

cu-o unică petală:

azi, mi-a dăruit-o un grădinar.

(„Zâmbetul meu pe buzele altora”- Disciplina harfei)

Nu am timp să dau tuturor o dovadă

a marilor, uimitoarelor mele virtuți.

Cine are ochi de văzut să vadă.

Altminteri, ochii mei rămân necunoscuți.

Sunt unii care, întâlnindu-mă, au spus:

„Bine-ai venit în viața mea, minune!“

Sunt alții care n-au avut ce spune

şi-am plecat de la ei, mai departe, în sus.

Timpul e iute. Mai am câte un dar

de preț - şi caut destinatari sub stele.

S-ar putea să-i caut în zadar;

şi-am să mă-ngrop, ca faraonii, cu bogățiile mele.

(„Orgoliu” - Disciplina harfei)

Volumul anului 1967, Destinele paralele, cuprinde şapte poeme lungi, spectaculoase, de largă respirație, răsturnare de stil pe care autoarea, mereu dornică să se ia la întrecere cu ea însăşi, învingându-şi rutinele, o defineşte - privind retrospectiv - drept „un neastâmpăr”. În esență, cele şapte poeme ample sunt conglomerate de mici poeme cu esență filosofică legate ideatic între ele şi numerotate, oferind un univers imaginar inedit, o demonstrație de acrobație cu metafore ingenioase.

Modul de viață al frigului

dă o ciudată impresie de ordine.

De fapt, sub liniile convenționale, bănuiesc o mişcare sălbatecă, fiecare stă cu dinții infipți

în carotida celuilalt, cu unghiile crescute în carnea celuilalt.

Sub transparenta placă de frig are loc un zilnic măcel, o foame care şi-a pierdut sensul, o concurență care şi-a pierdut scopul, cu cât fierberea e mai vicioasă, cu atât liniile convenționale sunt mai exacte şi mai distinse, ca epùrele desenate cu creta pe tabla neagră, care seamănă atât de bine cu fantomele.

(„Frigul”-11, Destinele paralele) 
După-amiaza e timpul intermediar.

Cei care iubesc nu au curajul să se anunțe.

Cei care sunt iubiți se lasă aşteptați.

Aşteptarea dilată nefiresc scaunele, turteşte telefonul ca o mare temperatură, pereții devin pneumatici, încât degeaba îți loveşti de ei capul, nu te trezeşte nicio durere; întreg universul este anesteziat.

(„Post Meridian” - 3, Destinele paralele)

Dacă n-ar fi fost vrăbiile, aş fi murit de mult, spuse copacul.

Mi-aș fi putut trăi moartea în voie, fără sutele de injecții sonore în pielea mea subțiată de exercițiul istovitor al verii, fără forfota feroce, contrazicând anotimpul solemn cu obscure reflexe, cu mirosuri indecente, cu pene, cu ciocuri, cu gheare, cu glasuri cine mai poate crede în demnitatea mea sau măcar în consimțirea mea la ritualul inefabil al iernii?

Ce mai puteam face eu, în acea derută, sub atacul lipsit de noblețe, cu însumi înjosit în ochiul soarelui?

(„Destinele paralele”- Orgoliul copacului, Destinele paralele)

Ambitus (1969) este un volum care străbate tematic zona instinctelor, prin ciclul de deschidere, intitulat 'Făpturi'; a sentimentelor - prin Lamento; a raționamentelor - prin ciclul Polemici- şi a stărilor de grație, prin ultima serie de poeme, Vraja. Un volum prin care poeta şi-a propus să afle „o posibilă cale de la fizic la metafizic, fără rigoare sau rigiditate, în ordinea fanteziei (şi a nesațiului trăirii complete)” (Cassian 1993, X), o aventură copleșitoare a intelectualității și emoției aduse laolaltă, a materialului înțeles prin prisma spiritualului, a iubirii trăite din perspectiva morții, într-un demers neo-modernist a cărui valoare şi originalitate nu pot trece neobservate.

Fanaticii celei de-a cincea roți, periculoşii vizitii lunari, cu părul verde tras adânc pe ochi ca nu cumva să vadă unde merg, cu mâinile străine de dârlogi, cu trup străin de cal şi rupt de şa, doar nuduri lungi sub faldul căzător al nopții sfâşiate în galop, doar nuduri oarbe călărind în sus spre globu-n care Degetul Enorm a scormonit o gură şi trei nări şi-a atârnat o lacrimă de praf 
de-un ochi inexistent, şi-a scris ceva

- ceva ce nu se poate descifra.

(„Poeții”- Făpturi, Ambitus)

Scrie, scrie, scrie, scrie, ciocârlie, cântă, vulpe blândă, crapă, crap de apă, scrie, scrie, scrie...

Lângă partea stângă un rar cărturar, peste palimpseste trece pana-i rece. Scrie, scrie, scrie...

A-nghițit un chit (cu-al lui bot, socot), mitul nenumit şi totemul tot. Cutie pustie.

Scrie, scrie, scrie...

Joc în soliloc.

Calfa scrie alfa.

Teta scrie beta.

Mama scrie gama.

Doi copii scriu pi.

Hârtie, sicrie...

Scrie, scrie, scrie...

(„Vrajă-n vrajă”- Vrăji, Ambitus)

Ambitus include, în partea de final, şi poemul „Donna Miraculata”, devenit azi cunoscut la nivel internațional pentru că, în anul 2014 - anul morții poetei - a fost inclus, în traducerea sa în limba engleză, în antologia celor mai frumoase 50 de poezii de dragoste ale ultimilor 50 de ani realizată, după o muncă meticuloasă începută cu ani înainte, de echipa de la Southbank Centre London, pentru a fi prezentată în zilele evenimentului tradițional londonez Festival of Love.

De când m-ai părăsit mă fac tot mai frumoasă, ca hoitul luminând în întuneric.

Nu mi se mai observă fragila mea carcasă, nici ochiul devenit mai fix şi sferic,

nici zdreanța mâinilor pe obiecte, nici mersul, inutil desfigurat de jind,

- ci doar cruzimea ta pe tâmplele-mi perfecte, ca nimbul putregaiului sclipind.

(„Donna Miraculata”- Vrăji, Ambitus) 
Anul 1969 este şi cel al apariției cărții pentru copii Povestea a doi pui de tigru numiți Ninigra şi Aligru, a cărei complexitate artistică depăşeşte cu mult granițele obişnuite ale literaturii pentru copii, putând fi citită ca o parabolă a iubirii fără sfârşit. Inspirată de legătura răsfățată a autoarei (Ninigra) cu soțul ei, Al.I. Ştefănescu, alintat Ali (Aligru), povestea în versuri are un farmec profund şi deschide porţile marilor jocuri lingvistice poetice ale Ninei Cassian, într-o revărsare spumoasă de har, de umor, de duioşie, de suspans bine temperat. Volumul, de altfel, a fost un mare succes de public şi de critică, fiind recompensat în acelaşi an al apariției cu Premiul Uniunii Scriitorilor.

Trecuse o săptămână de hărțuială şi chin.

Ninigra slăbea puțin câte puțin.

Noaptea scâncea, şi-n timpul zilei scâncea.

Deci, cum se zice, era vai şi-amar de ea.

Odată, când maimuțicile şi cu maimuța mare

plecaseră-mpopoțonate la plimbare.

Ninigra-n cuşcă spuse: „Ce-o să mai fie? Nu mai pot!

mi-e tigroază..." Când auzi o voce subțire de tot:

„Sunt papagalul Partiprì-Partiprì,

singura pasăre care poate vorbi,

singura pasăre care are

câte o pană din fiecare culoare.

Sunt papagalul fermecat

şi vreau să te ajut neapărat.”

Ninigra, de bucurie, începu să plângă,

şi din lacrima dreaptă, şi din lacrima stângă...

(Povestea a doi pui de tigru numiți Ninigra şi Aligru, Cap. V. Culoarea salvatoare)

Volumul Marea Conjugare din 1971 „trece aproape neobservat”, consemnează poeta în jurnalul său, deşi conține noi titluri memorabile, sub care dragostea trăită intens, lucid, dureros, îşi sclipeşte alte şi alte fațete poetice.

Deci, tot se face seară aci pe-orizontale

blesteme dezlegate; deci, tot se face seară

pe casta dezvelire a patimilor tale.

Deci, tot se face seară... pentru a câta oară?

Te lecuieşti de gestul sălbatic al luminii

când pârjoleşte roca. Îşi stinge păsăretul

culorile şi foamea. Şi-n timp ce suie crinii,

îşi pierd puterea macii degenerând cu-ncetul...

Deci, tot se face seară... 
O, dacă-ai fi ştiut,

puteai să-aştepți în voie şi nu gemând şi nu

recunoscând un sumbru păcat necunoscut,

şi nu dând zvon în lume că tu, şi tu, şi tu!

(„Dacă-ai fi ştiut...”, Marea Conjugare)

Anul 1971 este şi anul căderii în doliu, prin tulburătorul volum Recviem scris după moartea mamei sale. Poeta transfigurează durerea cumplită a celei dintâi despărțiri esențiale peste granițele morții, în poeme în care glasul sfâşietor şi țipătul de revoltă alternează cu tonul neputincios, grav sau recules.

Nu-mi vine că cred

nu că eu nu te văd

ci că tu nu mă vezi,

dulcea mea moartă,

fiind tot ce eram

şi cu ceea ce sunt

zilele mele, nopțile

sub ochii tăi petreceau.

Nu puteam să mă nasc,

nici să mor nu puteam

fără spinul senin

al privirilor tale,

şi un miros suav

de privire a ta

mă-nsoțea când sub cruce

un deal mă urca

spre cuiele definitive.

Cum poate să curgă

de-acum carnea mea

decât doar către tine,

dulcea mea moartă,

pentru că nu pot

fără privirile tale să fiu

când între eternități

mi se face târziu.

(“Cuiele definitive”, Recviem)

Cum puteți arunca vocile voastre

ca pe o lavă letală peste-obiecte?

Mesele cad cu picioarele-n sus.

Oglinzile devin erecte.

Pâinea se-ntunecă. Însuşi fumul, desfigurat de hohotul vostru, îşi pierde rostul,

îşi schimbă drumul.

Ce zarvă obscenă! Visez la moarte

ca la o curte pustie, 
ca la un țărm părăsit,

ca la un fund de cutie

în care numai tăcere

şi numai tăcere să fie.

(„Ospățul indiferenților”, Recviem)

Aşa cum Nina Cassian declarase în anii anteriori că „se dăduse drumul la dragoste”, în perioada următoare se dă drumul la joc şi la joacă. Poeta emoțională, poeta cerebrală, poeta intelectuală devine, cel puțin pentru o vreme, poeta ludică, ce se amuză şi reinventează lumea prin ochii unui copil genial, care creează nu doar un nou cod de interpretare a culorilor, a gesturilor, a peisajelor, a conceptelor esențiale...

Vine (când vine) ora de joc.

Mâna-i o fundă. Ochii - pisici.

Sfinții, martirii, se fac iarăşi mici

şi-n azime blânde se coc.

Ninge. Noaptea ne învelim

cu hârtie de poleială.

Ființa noastră mineral

sună ca un heruvim.

Ziua, ne lăcuim portocaliu

şi-avem degete iuți

cu care cârmim mai târziu

corăbii de argonauți.

Cât viața, cât moartea poate, ora de joc se dilată, ca după acestea toate, să-nceapă încă o dată.

(„Ora de joc”, Loto-poeme)

...ci inventează apoi chiar şi o nouă limbă, o limbă proprie, limba spargă, într-un demers ale cărui farmec, nebunie şi curaj sunt cu adevărat singulare în literatura română.

$\mathrm{Au}$ înmorit drumatice miloave sub rocul catinat de nituraşi.

Atâția venizei de bori mărgaşi...

Atâtea alne strămătând, estrave...

Nicicând guluiul arfic, bunuraşi, n-a tofărit atâtea nerucoave.

Era, pe când cu veli şi alibave,

Cozimiream pe-o şaită de gopaşi. 
Dar azi mai tumnărie-mi pare stena

cu care goltul feric m-a clăuns

şi zura-i nedă, mult elenteena...

Doar vit şi astrichie-n telehuns.

Îmi zurnuie, sub noafe, melidena

şi linful zurnuie, răuns, prăuns...

(„Sonet” - în limba spargă, Loto-Poeme)

Stilul ludic continuă programatic în Jocuri de vacanță (1983), ca un refugiu al artistei ce refuză căderile în dramatismul şi cenuşiul epocii, ca o nouă formă de regăsire de sine într-un ritm hohotitor, zâmbitor sau autoironic.

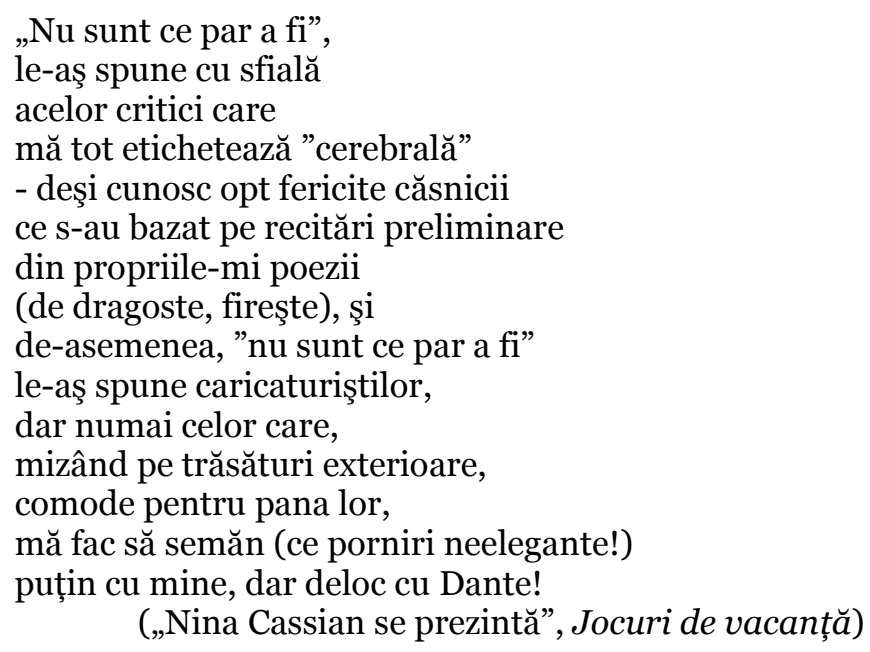

Ciclul Exerciții de stil din Jocuri de vacanță oferă un spectacol captivant al domesticirii, dresării, punerii la lucru şi răstălmăcirii limbii române în jonglerii de un umor nebun şi o virtuozitate plină de farmec.

Stavăr, filfizon de marcă,

Se trezise singur leoarcă.

Mult prea des, în viața-i scurtă,

Se îndrăgostise turtă

Ba de-o Lină, ba de-o Miță,

Pînă-ncărunțise criță.

Sigur, o făcuse fiartă.

Geaba protesta la toartă

Cum că nu e el acela

Care se îmbată lela,

Rătăcind pe pajişte,

$\mathrm{Cu}$ bocancii vraişte.

Nu că era bun de ocnă,

Dar se îngîmfase bocnă. 
Şi-astfel, toată viața lui,

S-a manifestat hai-hui.

Geaba, Stavăr! Gata, fete!

Azi eşti singur ciuciulete.

(„Expresii improprii”, Jocuri de vacanță)

$\mathrm{Nu}$ lipsesc, însă, din jocurile vacanței, tuşele profunde, privirile chiar şi cu coada ochiului - cu reflex metafizic.

A fost un an bun.

Au murit câțiva

dar eu sunt viu.

S-a prăbuşit un continent,

dar pe ulița mea

umblă câinii cu covrigi în coadă.

Se pare că vine o ciumă.

Poate pentru alții -

pentru mine, mumă.

(„Ego”, Jocuri de vacanță)

Ultimele trei volume publicate în limba română, cât autoarea se afla încă în țară, Suave (1977), De îndurare (1981) şi Numărătoarea inversă (1983), schimbă din nou expresia şi devin, sub imperiul întunericului din țară şi al ultimilor ani, mai îndurerați, ai căsniciei sale cu Al.I. Ştefănescu, mai reținute, mai interiorizate, mai îndepărtate de metafora explozivă.

Sunt un trup frumos care zadarnic respiră;

neatins de amurg, sănătos ca ploaia, neutru la sfintele-oferte-ale harului -

de ce să trăiască asemenea oarbe-animale?

Poate că, în neştirea mea, totuşi slăvesc

lucrarea Domnului - şi nici nu mai trebuie

învinovăţită pielea mea strălucitoare

şi alergarea mea triumfătoare printre mistere...

(„Sunt un trup frumos care zadarnic respiră”, Suave)

Şi iar m-am gândit să trăiesc

ca într-un joc fericit.

Nu mai voiam să sculptez monumentul

la care atât am râvnit,

ci doar să-mi aud dinții

ciocnindu-se de alune,

ci doar să-mi văd sângele ciripit

de frumoasele păsări nebune.

$\mathrm{Nu}$ se poate,-mi spune buna moarte.

Înțeleapta moarte-mi spune: nu se poate.

Trebuie să trăieşti ca şi când, 
ca şi cum,

avem întâlnire-n curând

sau acum.

(„Şi iar m-am gândit să trăiesc”, Suave)

În poeme se strecoară adesea aluzii subversive la adresa regimului comunist devenit insuportabil, a umbrelor din sufletele unui popor care resimte deja acut lipsa de libertate sau o stranie şi foarte delicată întoarcere spre invocarea rezolvărilor divine.

Din nou îmi e dat să respir

aroma de cimitir

a frumoasei naturi,

veşniciile ei iluzorii,

pacea ei mincinoasă,

falsa ingenuitate a florii.

Totul îmi pare o înscenare

a unei naturi, cu mult mai mare,

care ne vrea supuşi, dezarmați,

resemnați sub tălpi de-mpărați.

Dar uite că amurgul

vine către mine măreț

și mă plec şi spun:

Înălțate-mpărate, înălțați împărați,

mă supun, dacă vreți.

(„Tălpi de-mpărați”, De îndurare)

Nu e nevoie să fii vinovat

ca să-ți primeşti pedeapsa.

Uite ce-a pățit floarea:

abia apăruse, era roz între frunze,

şi-a venit animalul cel mare

şi-a suflat peste ea o insultă.

(„Fără vină”, De îndurare)

Pietricica spaimei

mi-a intrat în talpă.

Şchioapăt tot mai tare

prin această lume.

Cui să-i fie milă

de-o cămilă şchioapă,

chiar dacă deşertul

n-are pic de apă?

Dinții-mi cad, de spaimă.

Năpârlesc, de spaimă.

Vântul spaimei bate

nară şi cocoaşă.

Cui să-i fie milă 
de-o cămilă laşă

chiar dacă deşertul

n-ar demnitate?

(„Pietricica spaimei”, Numărătoarea inversă)

Cine mă sileşte să rămân în frig

lângă-o mare sumbră şi dezordonată, unde nu m-aude nimeni dacă strig, unde nu e faptă, unde nu-i răsplată?

Cine e stăpânul, veselul sau gravul, care îmi oblige vârful de grafit

ca şi cum mi-aş scrie însămi epitaful

şi ar fi urgență mare de murit?

(„Cine mă sileşte să rămân în frig”, Numărătoarea inversă)

După plecarea forțată din țară a Ninei Cassian (care, în 1985, este nevoită să rămână în America, întrucât este avertizată că, la întoarcere, o pândesc represiunile nemiloase ale regimului, cărora tocmai le căzuse victimă prietenul ei, Gheorghe Ursu) urmează o perioadă îndelungată de tăcere. „Printr-un accident al istoriei, am fost catapultată pe alt meridian”- priveşte poeta către anul marii schisme personale, 1985.

Volumul pregătit pentru publicare în 1985, Nocturne, va apărea abia 12 ani mai târziu, ca parte a titlului DesFacerea lumii, şi cuprinde poeme de doliu personal, față de pierderea soțului, şi de doliu colectiv, trăit în taină şi tăcere, față de pierderea curajului şi a speranței în fața dictaturii ce părea fără de sfârşit. Tonul redevine grav şi şoptit, metafora simplă, amară.

Coapsele, pântecul, sânii

- la ce bun?

$\mathrm{Cu}$ această alcătuire zadarnică

străbat plaja

ca pe-o ultimă bucată de lume,

însoțită de o oaie tristă.

(Cândva, am păscut împreună

mărarul de aur al stelelor).

Cerul e gol.

Mâine e noapte.

(„Nud”, Nocturne)

Se scumpeşte apa.

trebuie să-nvăț

să înot în praf

şi să beau noroi.

Păsările pleacă-n toamnă

şi la primăvară

nu vin înapoi. 
Se scumpeşte pânza-albastră.

trebuie să-nvăț

să mă-mbrac în negru.

Şi scheletul de peşte

se scumpeşte.

(„Vis cu secetă”, Nocturne)

DesFacerea lumii adună poemele scrise sub durerea reținută a strămutării într-o țară străină, într-o limbă străină - schimbare aproape ucigătoare pentru o făptură frenetic ancorată în universul lingvistic matern.

Mi-am părăsit pereții plini de sânge, de sângele meu

(a fost un teribil masacru)

acum zbor peste oraş,

dar nu ca o mireasă alături de mirele ei violonist,

ci ca un coşmar înaripat

cu o întreagă biografie de pene murdare.

Trebuia să fi plecat mai demult

înainte de a fi exterminată de singurătate

şi de haoticele topoare ale tăietorilor de oameni,

ale vânătorilor de capete, trebuia -

dar cine ştie oare cât se poate îndura?

Mereu aşteptăm, aşteptăm

şi trece ziua, trece viața,

în oasele noastre îşi croieşte canal caria neagră,

în ochii noştri se acreşte laptele luminii,

limba ni se umflă ca o ciupercă bolborositoare.

Dar eu am părăsit acei pereți şi acea casă a masacrului.

Eu acum sunt o zburătoare, o pasăre de coşmar -

fiecare $o$ aude fâlfâind,

nimănui nu-i vine să creadă că sunt chiar eu

iar eu, oricum,

refuz să-mi declin identitatea.

(„Exodus”, DesFacerea lumii)

Muzica de dincolo este volumul poemelor scrise în America, cel mai adesea în limba engleză, şi apoi traduse în română.

„Multă vreme n-am crezut că-mi va sta în putință asemenea transfer ideatic şi emoțional. Şi iată-mă traducându-mă în româneşte (compunând un nou original) - altă întorsătură de destin!" (Cassian 1997, 5) exclamă Nina Cassian în 1997, privindu-şi cu uimire noua poezie, noua viață, noua deznădejde a dezrădăcinării în care învață să trăiască din nou. 
Mereu mi se refuză ceva:

o portocală, o poezie, statutul uman -

identitatea mea, tot mai incertă;

degeaba îmi tot scriu numele pe cărți,

numele meu - o convenție,

ființa mea - o abstracție,

semne particulare -n-are.

(Ba da: o erupție a orgoliului pe obrazul stâng).

Până la urmă, refuzurile care mă asediază

îmi precizează făptura

aşa cum aruncătorul de săbii

- prin cele pe care le înfige în panou -

obține perfectul contur al victimei.

(„Înrămat”, Muzica de dincolo)

Dar cuprinde, dincolo de deznădejde, şi renaşterea printr-o nouă iubire, care o va vindeca şi o va întoarce, salutar, iarăşi la poezie.

...sunt aleasa dragostei lui târzii,

sunt prada întineririi lui,

mă pierd într-un miracol copleşitor,

nu într-unul blajin cum mi s-ar fi cuvenit la crepuscul...

Din uitate străfunduri, clamoarea de altădată

urcă invincibil:

„Te iubesc”, îi strig străinului, „vreau să împart cu tine

viața şi moartea şi muzica de dincolo"!

Şi străinul, într-o limbă străină, îmi repetă cuvintele.

(„Muzica de dincolo”, Muzica de dincolo)

Fără ca mediul cultural românesc să consemneze asta cu îndreptățita considerație, Nina Cassian a făcut o strălucită carieră artistică în Statele Unite ale Americii şi, astfel, i s-au deschis şi porțile recunoaşterii internaționale. În 1994, în America, i-a fost acordată de către New York Public Library, prestigioasa distincție „Library Lion”, pe care au mai primit-o de-a lungul anilor figuri importante ale literaturii mondiale ca Margaret Atwood, Kazuo Ishiguro, Zadie Smith, Ian McEwan, Gloria Steinem, Maya Angelou, Salman Rushdie.

În limba engleză a publicat volumele Blue Apple (1981), Lady of Miracles (1982), Call Yourself Alive? (1988), Life Sentence (1990), Cheerleader for a Funeral (1992), Take my Word for It (1998) Something Old, Something New (2002), Continuum (2008). Aceste ultime volume în limba engleză (traduceri sau originale) au fost publicate de editura americană W.W. Norton, care i-a inclus poemele în influenta serie „Selected Works”, aceasta fiind o performanță remarcabilă pentru orice autor al lumii sau de către la fel respectata editură Anvil Press din Marea Britanie. Numeroase poeme ale Ninei Cassian, având ca temă copilăria, 
exilul, dragostea sau căutarea libertății au apărut, de asemenea, în reviste foarte cunoscute precum The New Yorker, The Atlantic Monthly, New England Review sau American Poetry Review.

$\mathrm{Nu}$ s-a îndepărtat niciodată sufleteşte de țară, declarând că nu a încetat niciodată să scrie în limba sa maternă. De altfel, pe ultima sa antologie alcătuită şi prefaţată de ea însăşi (Cearta cu haosul, 1993) a lăsat scris, în loc de testament:

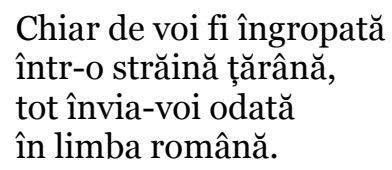

Nina Cassian şi-a trăit restul vieții şi a murit la New York, pe 14 aprilie 2014 - anul în care ar fi trebuit să împlinească 90 de ani. A murit în pace, fără suferință, adormind senină şi nemaitrezindu-se, aşa cum soțul ei Maurice Edwards şi-a anunțat prietenii printr-un e-mail reținut. A evadat delicat din viață şi din timp, lăsând, totuşi, urme de neşters prin opera ei.

„Timpul. Îi aud şuierul. Îi simt dintele - cu siguranță, un canin. Şi mă întreb: dacă ar avea un trup, ar putea descoperi cineva, undeva, urma muşcăturii mele?” se întreba Nina Cassian încă din anii tinereții. (Cassian 1970, 6) Răspunsul şi revelațiile rămân în seama noastră, a celor care o citim, recitim, răscitim pe Nina Cassian.

\section{Bibliografie}

Cassian, Nina. (1947). La scara 1/1. Bucureşti: Editura Forum.

Cassian, Nina. (1955). Versuri alese. Bucureşti: Editura de Stat pentru Literatură şi Artă.

Cassian, Nina. (1957). Vârstele anului. Bucureşti: Editura de Stat pentru Literatură şi Artă.

Cassian, Nina. (1957). Dialogul vântului cu marea - Motive bulgare. Bucureşti: Editura de Stat pentru Literatură şi Artă.

Cassian, Nina. (1961). Sărbătorile zilnice. Bucureşti: Editura Tineretului.

Cassian, Nina. (1963). Să ne facem daruri. Bucureşti: Editura pentru Literatură.

Cassian, Nina. (1965). Disciplina harfei. Bucureşti: Editura pentru Literatură.

Cassian, Nina. (1966). Sângele. Bucureşti: Editura Tineretului.

Cassian, Nina. (1967). Destinele paralele. Bucureşti: Editura pentru Literatură.

Cassian, Nina. (1969). Ambitus. Bucureşti: Editura pentru Literatură.

Cassian, Nina. (1970). Cronofagie. Bucureşti: Editura Eminescu.

Cassian, Nina. (1971). Recviem. Bucureşti: Editura Eminescu.

Cassian, Nina. (1971). Marea conjugare. Cluj: Editura Dacia.

Cassian, Nina. (1972). Loto-Poeme. Bucureşti: Editura Albatros.

Cassian, Nina. (1974). Intre noi copiii. Bucureşti: Editura Ion Creangă. 
Cassian, Nina. (1975). O sută de poeme. Selecția autoarei, în colaborare cu Şerban Foarță. București: Editura Eminescu.

Cassian, Nina. (1977). Suave. Bucureşti: Editura Cartea Românească.

Cassian, Nina. (1971). De îndurare. Bucureşti: Editura Eminescu.

Cassian, Nina. (1983). Numărătoarea inversă. Bucureşti: Editura Eminescu.

Cassian, Nina. (1983). Jocuri de vacanță. Bucureşti: Editura.

Cassian, Nina. (1993). Cearta cu haosul. Bucureşti: Editura Minerva.

Cassian, Nina (1997). DesFacerea Lumii. Bucureşti: Editura Fundaţiei Culturale Române.

Cassian, Nina. (2008) Spectacol în aer liber, O altă monografie a dragostei. Ediția a IIa, Bucureşti: Editura Cărțile Tango.

Cassian, Nina. (2010). Memoria ca zestre. Bucureşti: Editura Cărţile Tango.

Cassian, Nina. (2020). O mie de poeme, Bucureşti: Editura Cărţile Tango.

ICR New York, (2019). Nina Cassian evocată la New York în ipostaza de muziciană şi compozitoare, https://www.icr.ro/pagini/nina-cassian-evocata-la-new-yorkin-ipostaza-de-muziciana-si-compozitoare 